\title{
Exilios impropios y peregrinación profana: Juan José Saer y Witold Gombrowicz
}

\section{Improper Exiles and Profane Pilgrimage: Juan José Saer and Witold Gombrowicz}

\section{Resumen}

Después de haberse mudado a Francia en 1968 y de haber escrito gran parte de su obra en el extranjero, Juan José Saer comienza a regresar periódicamente a la Argentina a partir de los ochenta, y escribe a propósito del regreso y del exilio una serie de textos en los que alude a la figura de Witold Gombrowicz. En este trabajo se indagarán los vínculos, correspondencias y divergencias entre ambos. Como se verá, Saer ubica a Gombrowicz en dos series de viajeros e intelectuales. Por un lado, una serie anacrónica e intemporal que lo relaciona con viajeros de épocas disímiles y en la cual se destaca su singular percepción del paisaje nacional; por el otro, una serie histórica que devuelve al escritor polaco a las rivalidades literarias de su época (Borges, Caillois y el grupo Sur). Cada una de estas inscripciones abre una sugerente contemporaneidad entre las poéticas y los exilios impropios de Saer y Gombrowicz. La "perspectiva exterior" de este último le permitirá a Saer radicalizar una figura de escritor exiliado y excéntrico capaz de resistir tanto los "infalibles" valores de Europa como los deberes de identificación nacional; y configurar además formas disruptivas de percibir el paisaje de la zona en sus regresos al país.

Palabras claves

Juan José Saer, Witold Gombrowicz, exilio, nación, paisaje nacional

\begin{abstract}
After having moved to France in 1968 and having written a large part of his work abroad, Juan José Saer begins to periodically return to Argentina from the eighties, and writes a series of
\end{abstract}


texts on the subject of return and of exile in which he alludes to the figure of Witold Gombrowicz. In this work we will investigate the links, correspondences and differences between the two writers. As we will see, Saer places Gombrowicz in two series of travelers and intellectuals. On the one hand, an anachronistic and timeless series that connects him with travelers from dissimilar times and which highlights his unique perception of the national landscape; on the other, a historical series that returns the Polish writer to the literary rivalries of his time (Borges, Caillois and the Sur group). Each of these inscriptions opens a suggestive contemporaneity between the poetics and the improper exiles of Saer and Gombrowicz. The latter's "outside perspective" will allow Saer to radicalize an exiled and eccentric writer figure capable of resisting both the "infallible" values of Europe and the duties of national identification; and also configure disruptive ways of perceiving the zona's landscape on his returns to the country.

Keywords Juan José Saer, Witold Gombrowicz, exile, nation, national landscape.

Ahora nos toca a nosotros mirarnos en Gombrowicz (García, "Leer a Gombrowicz" 12)

Así cierra el homenaje que Germán García le dedica a Gombrowicz a propósito de su muerte en la revista Los libros de agosto de 1969. Una frase profética que se alza como un mandato generacional en relación con las nuevas maneras de hacerse un lugar en la literatura argentina y que rescata fundamentalmente la épica traducción colectiva en la que se aventuró Gombrowicz con su novela Ferdydurke, realizada junto a sus amigos y camaradas del café Rex. Leída retrospectivamente, esa consigna resuena en varios escritores que de diversas maneras "se miraron" en Gombrowicz: sus "discípulos", 1a "línea bastarda de exiliados filiátricos" que Gasparini reconoce en Copi, Perlongher y Lamborghini, y también Ricardo Piglia y Juan José Saer, entre otros que de distintas formas retomaron la mítica figuración del escritor polaco. ${ }^{2}$ Para el caso de Saer, la

\footnotetext{
${ }^{1}$ Así se reconocen a sí mismos Juan Carlos Gómez, Mariano Betelu, Jorge di Paola y Alejandro Russovich en la película de Alberto Fischerman, Gombrowicz o la seducción (1985).

${ }^{2}$ Cfr. al respecto el artículo de Paula Freixa Terrada "Gombrowicz como personaje de ficción en la literatura argentina".
} 
invitación a "mirarse" en Gombrowicz adquiere un inusitado espesor que excede la simple identificación y que le permite complejizar su propia noción de extranjería.

Como se recordará, en 1968 Juan José Saer viaja a París con una beca del gobierno francés para estudiar el Nouveau roman, y la estadía en principio acotada a seis meses se prolonga por el resto de su vida. Sin embargo, a pesar de quedarse en Europa y de coincidir cronológicamente con artistas e intelectuales de América Latina, Saer desarticula las expectativas culturales de visibilización, consagración y compromiso político asociadas al viaje del escritor latinoamericano y se muestra, desde un principio, indiferente y remiso tanto a la asimilación cultural francesa cuanto a la latinoamericana. Su experiencia en el extranjero lo lleva a desarrollar un sostenido pensamiento sobre el exilio y a calibrar la distancia con respecto a la “zona" sobre la que volverá en cada uno de sus textos.

Después de algunos años sin poder regresar al país, desde 1976 hasta 1982, Saer comienza a visitar periódicamente la Argentina e indaga las posibilidades e imposibilidades del retorno en escritos ficcionales y ensayísticos. ${ }^{3}$ Será precisamente allí cuando la figura de Witold Gombrowicz comience a aparecer en varias de sus reflexiones. En el conocido ensayo "La perspectiva exterior: Gombrowicz en Argentina"4, en El río sin orillas y en las Libretas de viaje el escritor traza su retrato y revisa parte de su obra a partir de una serie de preocupaciones que ya había tematizado muchas veces: ${ }^{5}$ el complejo vínculo entre

\footnotetext{
${ }^{3}$ De ese corpus de "textos del retorno" podrían formar parte las novelas El entenado, La pesquisa y La grande y algunos cuentos de Lugar, así como también El río sin orillas, las Libretas de viaje y varios de los ensayos incluidos en El concepto de ficción. En Relatos de regreso. Ensayos sobre la obra de Juan José Saer, Luigi Patruno revisa la vuelta como principio constructivo en la obra saeriana y analiza diversos tipos de retorno (el de los personajes de la zona; el de la vuelta a la narración y el del propio Saer a la Argentina). Según su lectura, los regresos - usualmente diferidos y fracasados-, no generan relatos de "recuperación" sino de "reflexión" a partir de los cuales Saer diseña una imagen de sujeto que opera sobre el territorio como si fuera un extranjero y no como alguien que vuelve a su hogar.

${ }^{4}$ Publicado originalmente en 1989 en Punto de Vista e incluido luego en El concepto de ficción (1997).

${ }^{5}$ En sus recorridos por distintos países pero fundamentalmente en sus regresos a la Argentina Saer llevaba unas Libretas de viaje que fueron publicadas en los Papeles de trabajo II. Borradores inéditos (2013). La mención de Gombrowicz se encuentra en la segunda libreta (Agenda 1989. Años noventa), cuando Saer estaba preparando algunos de los ensayos que luego formarían parte de El concepto de ficción y anotaba ideas para "La perspectiva exterior". En algunos casos retoma citas del Diario e imágenes que previamente había recolectado Gombrowicz, y también reflexiona
} 
la literatura nacional y la tradición universal y la paradojal figuración de un escritor exiliado. Gombrowicz irrumpe en un momento particularmente significativo de la trayectoria saeriana, allí cuando, después de un relativo pero prolongado anonimato en Francia, su obra comienza a ser leída y publicada en Argentina (ya no sólo por el círculo de fieles amigos y estudiantes de la universidad, sino por un público más amplio). Saer viaja regularmente al país para presentar sus nuevos libros, acepta entrevistas y participa de homenajes y festivales. ¿Por qué mirarse entonces en la ruinosa figura del excéntrico polaco, procaz y esquivo a los rituales y valores de la institución literaria? (porque es esa la imagen que privilegia Saer, y no la del posterior reconocimiento y consagración europea de sus últimos años en Berlín y Francia).

Gombrowicz vuelve como cifra de una resistencia y como el punto más radical de una serie de escritores y viajeros a través de los cuales Saer va figurando, fragmentariamente, sus formas de residir en el extranjero y de volver a la Argentina: desde Rubén Darío, el poeta iconoclasta que termina abdicando del conjuro de París, ${ }^{6}$ a los viajeros del siglo XIX que rubrican varias de sus ficciones y ensayos posteriores, y fundamentalmente en relación a los escritores exiliados que conforman su exigua y privilegiada biblioteca: ${ }^{7}$ una filiación del viaje y del exilio

\footnotetext{
sobre sus "temas": la juventud, la absorción del joven por el adulto, y el exilio. La lectura no es complaciente y busca desarticular ciertas aristas del mito Gombrowicz: su "pobreza" y la dura marginalidad de su exilo en las remotas orillas argentinas, además de criticar "cierto vitalismo ingenuo" del escritor. (Saer, Libretas 317)

${ }^{6}$ Saer conjura los primeros años de su experiencia francesa a partir de la escritura de poesías cuyo tema es el viaje y lo extranjero. En su gran mayoría, estos poemas ponen en escena a un sujeto lírico que se desplaza por París y se desdobla en una serie de escritores-viajeros -fundamentalmente Rubén Darío- a partir de los cuales puede situarse en la línea del "desencanto" de París. Las poesías “A Rubén Darío", inéditas hasta la publicación de Los papeles de trabajo, y "Rubén en Santiago" (El arte de narrar) permiten observar la filiación saeriana con la figura de Darío como viajero y residente en París. Esta versión crítica y pesimista, que retomaba el desencanto modernista, le permitió a Saer desarticular y oponerse al París de los sesenta y resistir otras imágenes cristalizadas del escritor-viajero: la del intelectual comprometido, la del embajador y representante de causas nacionales, la del escritor decidido a conquistar la legitimación de la metrópolis y la del escritor exitoso pero asimilado que adopta la lengua extranjera.

7 A lo largo de varios ensayos y entrevistas Saer ofrece una versión ampliada del exilio, como "situación de exterioridad" e intemperie que trasciende las causas políticas del destierro y del ostracismo: "la enfermedad, física o mental, la pobreza, la sexualidad, etc.... Entre los escritores de nuestro tiempo, hay exiliados voluntarios como Joyce, Beckett, Pound, Eliot, exiliados forzosos
} 
que da, con Gombrowicz, una nueva vuelta de tuerca, y que permite volver a leer algunos de los ensayos programáticos que Saer había escrito en los setenta sobre el papel del artista y la narración, y comprender también algunas de las experimentaciones más extremas sobre la percepción que el escritor había probado en novelas como Nadie nada nunca o El limonero real. ${ }^{8}$

Saer recupera la figura y la obra de Gombrowicz, en primer lugar, para confirmar su propia sustracción, ${ }^{9}$ pero además, y al mismo tiempo, para reafirmar sus elecciones estéticas y políticas en tanto escrito exiliado. Como se analizará, en "La perspectiva exterior: Gombrowicz en Argentina" y en El río sin orillas Saer lo incorpora en dos series de viajeros e intelectuales: por un lado, la serie anacrónica e intemporal reúne a Gombrowicz con una gran y heterogénea tradición de exploradores, marineros, científicos y comerciantes que recorrieron el territorio argentino, formalizaron las primeras imágenes del paisaje del Río de la Plata y fueron capaces de "iluminar y nombrar cosas que antes de su paso se confundían en un magma indiferenciado" (Río sin orillas 105). Saer destaca la singular

como Brecht, Benjamin, Gombrowicz, Vallejo, hay exiliados en su propia patria como Macedonio Fernández, Juan L. Ortiz, Svevo o Faulkner [...] y hay quienes se hallan fuera [...] por otras razones, como la enfermedad [Proust o Kafka], o en el ghetto de la locura, como Artaud" (Saer, Ensayos 150).

${ }^{8}$ Sobre el carácter "extremo" de la prosa saeriana, cfr. El silencio y sus bordes. Modos de lo extremo en la literatura y el cine de David Oubiña.

${ }^{9}$ En "Saer: un escritor del lugar", Julio Premat presenta a Saer como "un escritor borrado, sin imagen ni biografía, que delimita una presencia fuerte a través de la construcción ambivalente de un lugar y de una compleja gama de personajes de escritor" (29). En sus ficciones Saer escribe la vida intelectual de la ciudad y construye una fábula de pertenencia a un grupo, pero sus ensayos afirman, en cambio, su individualidad. Cuando se va a Francia -continúa Premat-, Saer se borra, y París se configura como un margen donde es posible escribir "no estando". En "El largo camino del silencio al consenso" Miguel Dalmaroni explica esas oscilaciones: Saer es, alrededor de 1964, un "iracundo a medio borrar", un joven que polemiza en encuentros y charlas de escritores y produce un módico revuelo en la vida literaria que llega hasta Buenos Aires. Sin embargo, cuando viaja a París, su figura se "asordina", se sustrae de la esfera pública y de las demandas políticas del compromiso a las que sí respondía la nueva literatura latinoamericana. Saer será durante muchos años el "escritor casi secreto", "silencioso", "ilegible", y también será, de acuerdo a las primeras críticas que recibieron sus textos, "mal leído", no interpretado. Serán sus amigos y lectores de Punto de Vista quienes produzcan el primer efecto de corrección y de reposicionamiento de su literatura en relación con nuevas morales de lectura y valoración estética. A partir de los ochenta, como se dijo, Saer ganará progresivamente una mayor visibilidad y con la publicación de Glosa se profesionalizará en tanto escritor que tiene un editor estable, participa de charlas, encuentros y entrevistas, y es traducido y comentado por un círculo cada vez menos restringido de lectores. 
percepción del paisaje nacional ofrecida por el escritor polaco y dialoga con ella en varios de sus textos más experimentales.

Por otro lado, una serie histórica devuelve a Gombrowicz a las rivalidades literarias y políticas de su contemporaneidad y a los azares que lo trajeron primero a la Argentina y lo llevaron luego a Europa. Aquí cobrarán importancia sus vínculos con Roger Caillois, Jorge Luis Borges y la constelación de escritores de Sur. Esta operación le permitirá a Saer radicalizar una figura de escritor exiliado y excéntrico a partir de cuya "perspectiva exterior" e "inmadurez" puede sedimentar una ética refractaria tanto hacia la pretendida superioridad europea como hacia los deberes de identificación nacional.

Interesará además en este trabajo no sólo advertir las sutiles y significativas resonancias que la obra y la figura de Gombrowicz tienen para Saer, sino también sus divergencias. El escrito polaco representa, en cada una de las series mencionadas, un principio de riesgo, un extremo de la imaginación geográfica y un desborde lingüístico que la sobriedad y la neutralidad saeriana no admiten, fingen desconocer o tergiversan. Por último, se buscará pensar de qué modos ambos escritores se vuelven contemporáneos en la impropiedad de sus exilios y en la configuración de poéticas que interrogan la percepción y ponen a prueba la fiabilidad de mundo y lenguaje.

\section{Ser nadie}

Pese al "egotismo incurable" del que suele acusárselo a Gombrowicz, y de la voluntaria "mostración" del "yo" que vendrían a ofrecer sus escritos, ${ }^{10}$ Saer confirma releyendo su Diario las operaciones de sustracción y escamoteo de la vida privada que siempre creyó fundamentales para elaborar una poética resistente a las presiones de la cultura: "Ser polaco. Ser francés. Ser argentino. Aparte de la elección del idioma, ¿en qué otro sentido se le puede pedir semejante autodefinición a un escritor? [...] A priori, el escritor no es nada, nadie" ("La perspectiva exterior" 17).

${ }^{10}$ Cfr. el "Final" de sus Peregrinaciones argentinas. 
Como se puede observar, el Diario argentino de Gombrowicz despliega una variedad de autofiguraciones y desdoblamientos cuyo efecto es, al contrario de lo esperado, la disolución de cualquier identificación estable: atraído por la juventud radical y demoníaca de Retiro, crítico del espíritu racional de Occidente y lúcido observador de los paisajes, la composición social y la literatura de Argentina, Gombrowicz es por momentos “'Witoldo', acriollado ya, aunque de vez en cuando aún [se] presenta[ra] como 'escritor polaco', [...] uno de tantos expatriados que hospedaba esta pampa, despojado hasta de la nostalgia por el pasado" (55) y también "un polaco, desconocido en París, autor de cierta obra, con gustos literarios demasiado paradójicos, sospechoso y excéntrico" (9) que se siente un extranjero exótico, ajeno de sí mismo en Goya, un pueblito de Corrientes, pero también un “Aristócrata en Tandil” (160) que a la vez desdeña y es atraído por la intelectualidad de provincias. Será más tarde, cuando esté de regreso a Europa, un "elemento ciego" (248) enamorado de Argentina; un viejo fantasma que se pasea en la cubierta del barco para encontrarse en el mar con su fantasma de la juventud, exactamente igual a él, a bordo del Chobry, el vapor que lo llevó hacia la Argentina en 1939, 24 años atrás, y finalmente un escritor "débil, disperso, disuelto" (261) que entra en Francia un poco enfermo y sabiendo que "como literato debía aislar[se] de París", ser su enemigo. Las últimas páginas del Diario lo encuentran pensando:

Ningún animal, batracio, crustáceo, ningún monstruo imaginario, ninguna galaxia me son tan inaccesibles y ajenos como yo. [...] Te has esforzado durante años en ser alguien, ¿y qué has llegado a ser? Un río de acontecimientos en el presente [...] el abismo, he ahí lo único tuyo. (262)

El escritor debe preservarse, señala Saer, de las cristalizaciones sociales que lo individualizan y lo enlazan a categorizaciones abstractas; y conservar un resto inclasificable: "Aunque tenga conciencia, como todo en mí, es más bien una semiconciencia y una cuasiconciencia. Soy semiciego. Soy casquivano. Soy de cualquier manera" (Gombrowicz citado en Saer 18). Esa indeterminación se 
radicaliza a partir del exilio, porque al igual que Saer, Gombrowicz también está hecho de una "encrucijada de destierros" y es quizás uno de los escritores que mejor encarna esa triple posibilidad del sujeto exiliado: ${ }^{11}$ como polaco que llega a Argentina por casualidad pero es sorprendido por la Segunda Guerra Mundial, la invasión nazi (y luego soviética) de Polonia y decide quedarse en el país, ${ }^{12}$ como sujeto exiliado de la sociedad y de los valores de la "cultura", a los que Gombrowicz les opondrá el carácter irruptor e indeterminado de la inmadurez, y finalmente acuciado por un exilio ontológico, aquel que lo deja continuamente sin patria y lo separa de sí mismo, aún durante su infancia en Maloszyce, cuando el entonces escolar polaco hacía todo lo posible para no marchar al ritmo de la orquesta militar, como advierte Gasparini para señalar que Gombrowicz inscribe allí, en ese momento de su infancia, el exilio como posibilidad y la Argentina como destino. ${ }^{13}$

\section{Peregrinaciones de un semiciego: Gombrowicz en la serie de los viajeros}

Como se adelantó, Saer no sólo recupera a Gombrowicz para afirmar el carácter resistente de su propia sustracción como escritor, sino también para indagar las alternativas estéticas y políticas del exilio, y para ello pliega y despliega su retrato en series más amplias de viajeros e intelectuales. La primera de ellas, intemporal y heterogénea, le permite a Saer definir la singular mirada del escritor

${ }^{11}$ En más de una oportunidad Saer distingue tres clases de exilios: el exilio circunstancial, aquel por el cual los sujetos se ven obligados a vivir en el extranjero por no compartir las ideas de los gobiernos que rigen sus países natales; el exilio de tipo estructural que le hace al hombre sentir los rigores de vivir en una sociedad alienada, incluso en su propia patria, y finalmente un exilio ontológico que es constitutivo del individuo y lo acompaña del nacimiento a la muerte. Concluye afirmando: "estamos hechos de esa encrucijada de destierros, de esa caja china de exilios y de carencias que desembocan en lo negro" (Ensayos 149) y particulariza la situación del exilio en la obra de un escritor, para quien supone un "alejamiento, una privación, una explosión [...] una especie de intemperie [...] que tiene al menos una ventaja: permitirnos ver desde afuera el conjunto que nos ha expelido" (149). Saer expande así la definición de exilio y la lleva del plano político al plano ontológico.

${ }^{12}$ En "Exilio y paralaje", Nicolás Hochman relativiza esta hipótesis, esgrimida por gran parte de la crítica y formulada por el mismo Gombrowicz en su Diario y advierte que el Chobry partió de Argentina antes de que estallara la guerra, es decir que la decisión de Gombrowicz de quedarse en Argentina no estuvo motivada por la invasión de Polonia, lo cual aumenta la gratuidad radical de su elección.

${ }^{13}$ Esta es la cita completa que retoma el libro de Gasparini: “[...] pero la Argentina, desde mi infancia, ¿no estaba ya inscripta en mis destinos, cuando aún escolar, en Polonia, durante los desfiles, hacía todo lo posible para no marchar al ritmo de la orquesta militar?” (30). 
polaco, a quien, entre una gran variedad de exploradores -Pigafetta, Schmidel, Félix de Azara, Millau, Mac Cann, Woodbine Hinchliff, Alfred Ebelot, Albert Londres y W.H. Hudson-, le tocó distinguir y sacar del magma indiferenciado la juventud baja de Retiro, "los adolescentes pobres y un poco venales que frecuentaba Gombrowicz" (Saer, Río sin orillas 105) pero a quien también le cupo observar de un modo novedoso el paisaje nacional. El Diario y las Peregrinaciones argentinas no sólo registran sus desplazamientos por las diferentes ciudades y regiones del país sino también los cambios sutiles que sufre el ojo del escritor cuando se mueve y observa. Saer destacará:

Y está también su percepción clara de la luz de Santiago, del aire transparente y feliz de Tandil, de la peculiaridad del espacio americano en Necochea, una impresión planetaria, cósmica, la sensación de un presente sin memoria prolongándose a su alrededor hacia el infinito. ("La perspectiva exterior" 22)

A continuación, el ensayo cita un fragmento del Diario en el que el escritor polaco proyecta, por sobre los límites geográficos y visuales de la playa de Necochea, un espacio ilimitado: "Vacío y arena, oleaje...estruendo que se ahoga y adormece. Espacio, distancias sin fin. Frente a mí y hasta Australia sólo esta agua surcada de melenas brillantes, al sur las islas Falkland y las Orcadas y el Polo. Tras de mí, el interior: Río Negro, la pampa...” (Gombrowicz en Saer 22). Sin embargo, desde ese punto específico en el mapa, se aleja hasta que "su recuerdo llega a desaparecer, y no queda sino el mero hecho de alejarse, incesante, eterno, como un secreto que llevara conmigo" (22). Saer captura a Gombrowicz en el momento en el que se despega del paisaje, tomado, como dice más arriba, por una "impresión material, cósmica". El ojo de Saer y el ojo de Gombrowicz producen a menudo estas derivas, prendidos de lo más inmediato: la melena brillante del mar o la textura 
lumínica del río, derivan en ocasiones hacia un sublime cósmico. ${ }^{14}$ Pero además, en varios momentos del Diario Gombrowicz reflexiona sobre las imposibilidades, carencias y dificultades de su visión, que por lo tanto dará muchas veces paisajes distorsionados y difusos que no distan demasiado de las imágenes que ensaya Saer en algunos de sus textos más experimentales. ${ }^{15}$

En varias oportunidades, como decíamos, la mirada de Gombrowicz exhibe su propia extrañeza: 'Usé la expresión 'me pareció ver' porque no creo que aquello fuera posible. Además estoy dudando, y el sombrero, el resplandor y los matorrales limitaban el campo de visión" (Gombrowicz, Diario 30); "No sé nada, quizá miro el paisaje al revés, pero no logro ver sino mosquitos, franjas, puntos, temblor de atmósfera, zumbido bañado en resplandor [...] y el sudor lo inundaba todo y todo se borra" (Diario 30-31). Más adelante, bajo un apartado titulado "Geografía" reconoce: "el mundo tangible de los árboles, la tierra, las hojas, este único mundo amistoso y fidedigno, se esfuma en una especie de no-visión, no-existencia... se borra" (Diario 107). Es decir, a diferencia de varios de esos viajeros enumerados por Saer cuya pretensión era precisamente conocer el territorio, determinar la productividad de sus tierras y establecer puntos estratégicos para el avance militar, económico o científico a partir de una mirada pragmática y efectiva que

${ }^{14}$ En la entrevista que le realiza Fernando García, "Saer en la ruta del adiós a su geografía literaria" (2015), Saer reconoce la insistencia de "lo arcaico" en su obra, en las distintas formas de lo subconsciente, lo biológico y lo sexual, pero también en "lo cósmico": "hay una presencia constante. Cuando se habla de lo ígneo, lo gaseoso. La referencia a la materia dispersa del universo que dio lugar al sistema solar" (191).

${ }^{15}$ Podrían mencionarse, entre otras ocurrencias: el rectángulo negro en el que se desintegra el mundo de El limonero real o la disolución puntillista de la experiencia del bañero en Nadie nada nunca; también, por supuesto, el blanco suprematista que condensa y ralentiza, detiene, la percepción en "A medio borrar" o el empaste informalista de la ciudad en Glosa, que toma los cuadros atormentados de Rita Fonseca, acribillados de manchas y drippings, como la forma legítima de la urbe. En El río sin orillas Saer precisará los efectos distorsivos de la llanura, que perturba las percepciones en dos sentidos: por un lado, en tanto espacio vacío que facilita la proliferación de lo idéntico y sigue una tendencia serial y repetitiva; y por el otro, volviendo abstracto aquello que lo atraviesa: "al cabo de cierto lapso la percepción ya no ve un caballo, tal como lo conocía en su campo visual, sino una masa oscura y palpitante, un ente problemático [...] que adquiere la nitidez enigmática de una visión" (120). Como se consigna en el cuerpo del texto, la mirada que Gombrowicz vierte sobre el paisaje argentino experimenta toda clase de distorsiones: borraduras, manchas, abrupta disgregación en formas geométricas, aparente ceguera, cuyo efecto es similar al de Saer, precisar el momento en el que el "sentido" abandona lo real, y hace tambalear las certidumbres cognoscitivas. Advertirá, por ejemplo, en las Peregrinaciones argentinas: "cada cosa, aquí, aparte de su propia existencia, posee otra, solar, en la que se vuelve irreal” (112). 
implementaba instrumentos de observación y medición, la mirada distorsiva de Gombrowicz, como también será la de Saer, captura el territorio en la potencia de su devenir, ${ }^{16}$ desmaterializándolo y convirtiéndolo en una visión, pura imagen que erradica las certezas sobre mundo y sujeto. Allí donde tanto Saer como Gombrowicz se vuelven extranjeros del paisaje y escriben sobre los restos de ese alejamiento: borradura, mancha, disolución y ruinas de un sublime cósmico se vuelven las formas que atestiguan la peregrinación profana de sus caminatas y paseos por Argentina.

En Caminantes, Edgardo Scott advierte que el peregrino es por lo general alguien "sin tierra" que a la vez puede hallar un hogar en cualquier sitio, y caracteriza al peregrinaje como la forma ejemplar de la caminata actual, tanto por la causa que la alienta, la fe, como por el rigor que exige. Las caminatas y paseos de Gombrowicz y Saer podrían ser, acaso, formas profanas de peregrinar por Argentina, en el sentido en que Giorgio Agamben entiende la profanación como neutralización y restitución al uso común. Peregrinar se vuelve aquí la forma de una sustracción y una suspensión de las formas "sacralizadas" de lo nacional y permite la apertura del paisaje a formas olvidadas e insospechadas, fugaces, de hacer experiencia.

De esta manera, los recorridos por el territorio argentino que Saer y Gombrowicz ensayan en El río sin orillas y en las Peregrinaciones argentinas inscriben lo nacional como deriva anómala: ${ }^{17}$ ambos textos estaban en principio

${ }^{16}$ En El espacio literario, Blanchot señala que "vivir un acontecimiento en imagen no es desprenderse de ese acontecimiento, [sino] dejarse tomar, pasar de la región de lo real, en la que nos mantenemos a distancia de las cosas para disponer mejor de ellas, a esa otra región donde la distancia nos retiene, [...] lejanía inapreciable que se ha transformado en la potencia soberana y última de las cosas" (250). Según continúa explicando, vivir un acontecimiento en imagen podría vincularse entonces con esa experiencia profundamente exiliar que separa, cada vez, al escritor del mundo y de sí: "lo que ocurre se apodera de nosotros como lo haría la imagen, es decir, nos despoja de ella y de nosotros, nos mantiene en el afuera, hace de ese "afuera" una presencia donde 'Yo' no se reconoce." (251)

${ }^{17}$ En "Lo incalculable: Saer en la escuela", Miguel Dalmaroni, retomando una idea de Esteban López Brusa, imagina el reemplazo del Facundo por El río sin orillas en el canon escolar, una opción que, inscripta en la línea del ensayo de interpretación nacional, vendría a marcar su fin, allí cuando el "intelectual", pleno de responsabilidades civiles, es sustituido por el escritor-artista que se sustrae de sí. La crítica ha caracterizado El río sin orillas como el "des-ensayo" del no-ser nacional escrito por un apátrida "que insistía en la inconsistencia de la identidad" (Dalmaroni, "Lo 
destinados a un público europeo y por lo tanto diseñan una serie de correspondencias y divergencias entre el escenario extranjero y el argentino; ${ }^{18}$ ambos enuncian las singularidades del paisaje desde una "perspectiva exterior" y producen una serie de desplazamientos genéricos (entre el ensayo como forma, la crónica de viaje, la ocasión biográfica o la crítica literaria). Sin embargo, allí donde Saer abjura del "color local", ${ }^{19}$ Gombrowicz dibuja una vuelta sobre el tan temido "exotismo" para fundar allí el potencial inexplorado de la inmadura, aún "informe", nación:

¿Qué ha ocurrido? El argentino, habitante de ciudades, de buena gana se olvida, en medio de sus calles llenas de iluminadas tiendas, del desierto salvaje, de la pampa y de la jungla que acechan en lo hondo del país, prefiere ignorar la existencia de lo primitivo en su propia casa. (Peregrinaciones 97)

Gombrowicz diferencia las actitudes de sus compatriotas polacos -generalmente asociadas al exceso de gestualidad, a lo artificioso y a cierta locura; pero también a la delicadeza y al refinamiento de sus platos culinarios ${ }^{20}$ de la

incalculable" 47); y como un artefacto dislocado y monstruoso que descalabra formatos genéricos, fábulas de identidad y mitos de origen" (Gerbaudo 179).

${ }^{18}$ Las Peregrinaciones argentinas (1977) son una serie de charlas radiofónicas que Gombrowicz confeccionó a partir de 1956 para la Sección Polaca de Radio Free Europe. Se desconoce si efectivamente llegaron a transmitirse pero fueron halladas por Rita Gombrowicz, años después de la muerte de su marido, junto a otra serie de colaboraciones para la radio, los Recuerdos de Polonia, ambas publicadas póstumamente en París en 1977. Como estas colaboraciones estaban dirigidas a los oyentes polacos que en ese momento se encontraban aislados culturalmente de Occidente por el régimen comunista instalado en su país, en muchos momentos Gombrowicz establece comparaciones entre Argentina y Polonia. Por otro lado, y como el mismo Saer lo advierte en la introducción, El río sin orillas fue un libro por encargo dirigido principalmente a lectores europeos, por lo tanto el escritor se ve en la necesidad de explicar algunos rasgos del paisaje rioplatense que serían evidentes para el lector argentino.

${ }^{19}$ En El río sin orillas declara explícitamente su posición al respecto, y ante el efecto que causó en él una tormenta impresionante que se desató sobre Buenos Aires, aclara: "tan impresionante que más de un lector podrá sospechar que, a causa de los riesgos de pintoresquismo -semejantes a los riesgos decorativos de toda obra pictórica- de la empresa en que me debato, me dejo tentar, teniéndome incapaz de despertar una curiosidad más elevada, por el color local” (33).

${ }^{20}$ Así como en varias ocasiones Gombrowicz lee el "gusto literario" en relación al "gusto culinario", aquí modela el carácter nacional a partir de su relación con la comida y confiesa que lo que verdaderamente extraña de Polonia es su cocina aristocrática y refinada: "[la] carne de cocido con 
monótona sencillez argentina - caracterizada con los signos de la mesura, la ausencia total de extravagancia y la belleza que, por ser expresión de lo corriente, no revela nada insólito ni maravilloso- pero recupera, en el reverso de esa indiferenciación y neutralidad, una forma exótica de pensar la nación que la sociedad burguesa y radicalmente urbana del país ha olvidado: la naturaleza indómita, salvaje y primitiva. $^{21}$ Así, en más de una oportunidad, el viajero corresponsal se autofigura como un aventurero que ha llegado a "lugares perdidos en el mapa" (Peregrinaciones 25). Será en esos parajes aislados -las cumbres del Aconcagua, el vertiginoso movimiento de las cataratas del Iguazú y el anchísimo Paraná que desemboca en bosques salvajes- donde pueda precisar la distancia entre la naturaleza doméstica de Polonia y la sublime naturaleza argentina, ${ }^{22}$ donde "todo es salvaje, inhóspito y monumental" (66). Sin embargo, a diferencia de la actitud nacionalista de sus compatriotas que, si contaran entre sus tesoros naturales al Aconcagua, cifrarían su encanto en su "polonidad", la actitud política de los argentinos es "imperialista" y posee una "escala intercontinental”. De la naturaleza a la política, Gombrowicz define el carácter nacional del argentino apelando precisamente a su monumentalidad geográfica y natural, y a la indeterminación productiva de los límites del país: “el nacionalismo argentino es de amplias miras

\footnotetext{
rábano picante, [las] setas en nata, [los] rollos de carne de buey o [los] raviolis con ciruelas" (44) que el polaco devora por placer, en nada comparables a las sopas argentinas "sin imaginación", sus salsas "sin alas" o sus "triviales" pasteles, que el argentino come por necesidad.

21 "Primitiva" no adquiere un matiz peyorativo sino asociado a lo que aún no tiene "forma" y está en ciernes. Gombrowicz se separa de aquellos compatriotas polacos que al llegar al país lo observan desde su "posición europea" y no reconocen ni la superior calidad de vida que se experimenta en muchos lugares de Argentina ni el carácter misterioso, refinado y sutil de su cultura, enriquecida por un insólito cruce de razas y costumbres de grupos inmigrantes que han llegado de todas partes del mundo.

${ }^{22}$ Por supuesto, esa preponderancia de la "naturaleza" ya había sido inscripta en esa gran experiencia de "reinvención ideológica" de América que Mary Louise Pratt analiza en Ojos imperiales: un extenso proceso de alcance transatlántico mediante el cual Europa redefinió su(s) imágene(s) sobre América Latina, fundamentalmente, a partir de los viajes de exploración de Alexander Von Humboldt, que definió a América como Naturaleza indómita, sublime y atractiva que podía y debía ser capitalizada por los afanes exploratorios y expansionistas de las élites europeas. Sin embargo, interesa aquí el modo en el que se reactualiza esta tradición en las peregrinaciones de Gombrowicz, como un gesto que a la vez le permite singularizar su mirada sobre el territorio argentino pero también subrayar las diferencias con esa Polonia rural y arcaica que él recuerda, más cercana, como anota Amícola, a las pequeñas comunidades de provincia que también recorre el escritor.
} 
y respira como esas montañas que, con su inmensidad, derrumban fronteras del Estado y se convierten en propiedad de América" (Peregrinaciones 70). Argentina es para Gombrowicz un espacio abierto al resto del continente, por cuyo vacío se disparan los vectores de la mirada:

al sur, Tierra del Fuego, al este, África, Europa; al norte, Estados Unidos... Argentina, perdida tímidamente en un rincón del mapa, en realidad está expuesta a los vientos más lejanos [...]. ¿Y Polonia? Arrinconada entre tantos países pequeños [...] asfixiada, con ese Báltico retorcido, apenas unido al océano por unos estrechos, desprovista de una forma geográfica, imprecisa... [...] Polonia debería sentir la llamada del más extremo universalismo, porque sólo así podrá compensar su situación geográfica. (71)

Gombrowicz parece invertir la fórmula sarmientina, "el mal que aqueja a la Argentina es la extensión" (Sarmiento 29), porque es en esa distancia donde se cifra el acervo inexplorado de lo natural como resto exótico que cabría redescubrir:23 así, por ejemplo, la zona subtropical del Alto Paraná "no es una zona segura. Los hombres y los reptiles, los ríos y los insectos, la tierra y el cielo, todo aquí es primitivo y está impregnado de la soledad del mundo salvaje" (Peregrinaciones 90). Esta reconstrucción exotista llega incluso a poblar de "monstruos" la selva y a sospechar de las comodidades burguesas, "civilizadas" de las que disfruta el viajero mientras penetra "como si nada en la virginidad de un bosque salvaje" (91).

Se recordará que Saer comparte esta zona geográfica en su literatura pero que procede a la inversa. Así, mientras camina, viaja en colectivo o se detiene a observar el río desde un puente, interroga la textura botánica, topográfica y lingüística del paisaje rioplatense como si fuera, por momentos, un naturalista aficionado o un viajero explorador. Sin embargo, esa indagación que

23 "Tierra del Fuego, para un habitante de Buenos Aires, es algo mucho más lejano que para un parisino" (Peregrinaciones 90). 
aleatoriamente va asentándose a través de las notas en sus Libretas de viaje y ordenándose en El río sin orillas no está sólo interesada en señalar lo absolutamente singular de la zona, sino también en indicar su parentesco disolvente con el mundo. Saer desarticula el "color local" apelando a una historización de larga duración capaz de saltar de la captura del instante al tiempo de los orígenes geológicos y cósmicos del universo:

lo exterior de un lugar no es más que la manifestación de algo que no es propio de ese lugar y que está, no propiamente en ninguna parte, sino en todas, lo que equivale a decir lo mismo. Los grandes ríos que forman el de la Plata, multiplicándose a medida que bajan del norte [...] no tienen nada de exótico y son el resultado de una serie de contingencias geológicas, geográficas y humanas en las que, por debajo del color local, el Logos común prosigue el soliloquio de su empastamiento con el mundo. (Río sin orillas 219-20)

En Peregrinaciones argentinas, Gombrowicz afirma su condición de forastero y señala, con una convicción casi modernista: "desde el punto de vista estético, el exotismo no sólo es bello y noblemente misterioso, sino también es una forma de huir de la suciedad, preocupaciones y luchas de cada día" (114). Como se recordará César Aira recupera precisamente la vía exótica para refundar los vínculos entre literatura y nación. Sandra Contreras analiza su conocido ensayo, "Exotismo", en relación al ensayo borgeano "El escritor argentino y la tradición", como una vuelta que, siguiendo el derrotero sinuoso del género, no apela a sus hipótesis más conocidas sino a una forma condicional del lenguaje en la que se concentra, sin embargo, la potencia de la perspectiva literaria: el "como si", el momento en el que, hablando de Shaw, Berkely y Swift, Borges señala que no importa que estos escritores fueran descendientes de ingleses porque el "hecho de sentirse irlandeses" era suficiente para que pudieran innovar en la cultura inglesa. Ante la disolución de las nacionalidades que Borges y Saer ensayarían hasta 
volverlas in-diferentes, Aira, señala Contreras, convierte el exotismo en una vía de regreso para afirmar la nacionalidad pero ahora sostenida sobre una "tradición potencial" (inactual, anacrónica).

Gombrowicz, como parte de esa tradición potencial, traza una diferencia inasimilable no sólo en la serie de los viajeros, sino con respecto al mismo Saer porque trae, del extremo geográfico del país, ese resto "exótico" -primitivo, salvaje ${ }^{-24}$ contra el que varias generaciones de escritores de la tradición nacional habían polemizado -incluso reconociéndolo, como Sarmiento, para erradicarlo; o bien disolviéndolo en la neutralidad universal, como Borges, o en la contingencia geológica y cósmica, como Saer- y se atreve incluso a barroquizar el espacio en mezclas aberrantes: la pampa corsaria que exhibe en su casa Gonzalo, el Puto de Transatlántico, en la que se yuxtaponen especies vegetales y animales exóticos y las más heterogéneas obras de arte. ${ }^{25}$

\section{"Y el gusto se les alborote por completo": Gombrowicz en la serie de sus contemporáneos}

"Mi deseo es ser un maestro de cocina que prepara sus guisos con manteca fresca y hace el consomé con la carne viva de la contemporaneidad."

(Gombrowicz, Peregrinaciones 154)

La segunda serie de viajeros y escritores en la que Saer incorpora a Gombrowicz, fundamentalmente en el largo retrato que traza en El río sin orillas, devuelve al escritor a su historicidad y al campo de rivalidades literarias en el que se desarrolló su particular escritura. Esta reubicación instala una sutil distancia

\footnotetext{
${ }^{24}$ Aira reconoce en "Exotismo": "El americano no necesita viajar tanto como el europeo; en sus países inconexos, a medio hacer, encuentra mitades exóticas mirando por la ventana" (78).

25 "Dos horas después llegamos a la verja de un gran jardín que, en la planicie inmensa de la Pampa, disparaba al cielo sus penachos de Palmeras, Baobabs y Orquídeas. Y cuando se abrió la reja, apareció una Avenida Penumbrosa, sofocante que conducía a un Palacio pesadamente dorado, de arquitectura Morisca o Renacentista, Gótica o también Románica, todo en una vibración de Colibríes, Moscas grandes, doradas, Mariposas multicolores y distintas clases de Papagayos" (Gombrowicz, Transatlántico 104). La casa de Gonzalo semeja una nave corsaria en la que los "tesoros" (105) de la cultura y de la naturaleza, lujosos y extravagantes, terminan "abaratándose", despreciándose mutuamente por su abundancia excesiva y su amontonamiento desjerarquizante.
} 
histórica entre Saer y el escritor polaco, quienes coincidieron en París el año del arribo de Saer (Gombrowicz muere en 1969) y resuelve esa diferencia en términos generacionales: "Para la gente de mi generación, en 1960, Sur en tanto que revista no era más que un soplo del pasado, [...] pero cuando Caillois y Gombrowicz llegaron al Río de la Plata, los escritores de Sur dominaban la escena cultural" (Saer, Río sin orillas 153$).{ }^{26}$

Saer comparará en El río sin orillas a Gombrowicz con Roger Caillois. Ambos llegaron circunstancialmente el mismo año de 1939 pero debieron quedarse por el estallido de la guerra y la ocupación de sus respectivos países y se transformaron, como lo haría el mismo Saer en Francia, de ocasionales viajeros en "huéspedes". ${ }^{27}$ Sin embargo, a pesar de estas coincidencias, sus derroteros intelectuales fueron prácticamente opuestos.

Roger Caillois, escritor a quien Saer efectivamente conoció en París a través de César Fernández Moreno, fue invitado por Victoria Ocampo e integrado al grupo de escritores de Sur, y funcionó, dice Saer, como un embajador de la Francia Libre. Editó la revista de Letras Francesas financiada por Ocampo en la que escribieron muchos de los intelectuales y escritores franceses censurados durante la ocupación y exiliados en distintas partes del mundo. Gombrowicz, en cambio, llegó sin ser invitado por nadie y desde un país marginal y si bien intentó tejer algunas relaciones

${ }^{26}$ Como se sabe, Saer irá construyendo su propia figura a partir de una serie de polémicas, deliberados silencios, demoras, filiaciones fluctuantes y reconsideraciones sobre diversas estéticas, escritores y posicionamientos políticos, y como se verá, algunas de sus opiniones no serán, pese a la distancia generacional, tan distintas de las que sostenga Gombrowicz cuando se refiera al panorama de la literatura nacional. Como señala Miguel Dalmaroni en "El largo camino del 'silencio' al 'consenso'. La recepción de Saer en la Argentina (1964-1987)”, Saer se distancia y es en un comienzo ilegible "para casi todos: la nueva izquierda comprometida, los intelectuales revolucionarios, los entusiastas de la 'nueva novela latinoamericana' o del Boom, los partidarios de Julio Cortázar o de Gabriel García Márquez, los detractores de Borges" (613). También Premat en "Saer: un escritor del lugar" repasa estos desacuerdos: "contra los imperativos del regionalismo o del realismo en los años sesenta; como oposición al Boom, al realismo mágico, al exilio y el sufrimiento como pathos del escritor rioplatense (en los setenta), la puesta en duda del culto a Borges, pero también el rechazo hacia operaciones literarias que integran literatura y comercio (propuesta de Umberto Eco). Crea entonces una filiación paralela, leyendo en otros los propios principios o leyendo lo que en los otros vendría a justificar la propia obra" (194).

${ }^{27}$ La perspectiva del "huésped extranjero" instala, como advierte Joaquín Manzi en "1939 y después: el largo invierno austral de Gombrowicz y Caillois", una relación asimétrica entre la intelectualidad argentina y la europea pero también los lazos de reciprocidad y obligaciones mutuas que exige toda relación de hospitalidad, una constante en la literatura argentina. 
con la revista Sur y publicar allí la traducción al español de Ferdydurke (1947), el encuentro entre Silvina Ocampo, Borges y Bioy Casares organizado por Mastronardi no tuvo efectos posteriores. El retrato de Gombrowicz se contrapone a la semblanza ascendente de Caillois, para enfatizar su "hundimiento progresivo y penoso en la pobreza, en la impotencia y en el anonimato" (Saer, Río sin orillas $155):{ }^{28}$ justo es reconocer, argumenta Saer "que en ese falso conde polaco, siempre al borde del desmoronamiento, roído por la miseria, el desaliento y la mala salud, había algo de inquebrantable y de heroico" (Saer, Río sin orillas 156). ${ }^{29}$

Saer encuentra en esta figura los atributos de una resistencia que va a contrapelo de las expectativas culturales y políticas de la época, otra forma de la refracción ética que el mismo Saer asumiría en 1968 y posteriormente. A diferencia de Caillois, que llevó adelante una tarea de diálogo cultural entre los valores de su patria y los de la nación anfitriona, Gombrowicz se negó a cumplir esta tarea y no actuó como el portavoz de Polonia porque su manera de pensar la nación se lo impedía, aun sabiendo que hubiera sido amparado por la institución literaria si se

${ }^{28}$ Similar procedimiento había ensayado Saer con otras figuras de artistas como la de Rubén Darío "al que pasean como una puta decrépita, de país en país, medio borracho" ("Rubén en Santiago" 71), o Fernando Espino, a propósito de quien escribe una semblanza como el pintor que encarnó "el arquetipo ideal del artista, en conflicto constante con el conformismo de su época y con sus propias tendencias autodestructivas" (Saer, "El pintor Fernando Espino", Ensayos 193) y que reúne todos los atributos que Saer entenderá como necesarios en un verdadero artista: iconoclastia, independencia artística, carácter salvaje y bohemio, divergente y polémico con respecto a los pintores oficiales. Como en el caso de Gombrowicz, Saer convierte los exabruptos del "malditismo", la borrachera y la impertinencia, en los atributos del héroe e invierte positivamente los signos: "aunque la mayor parte del tiempo su conversación se limitaba a gruñidos, a sarcasmos musitados y a ironías desdeñosas y críticas [...] nunca puse en duda ni su gusto ni su fineza, ni su inteligencia crítica, de los cuales su propia pintura era la prueba irrefutable" (Saer, "El pintor Fernando Espino", Ensayos 194).

${ }^{29}$ En "El diario trans-atlántico de Witold Gombrowicz" José Amícola advierte la figuración contradictoria de Gombrowicz, que si por un lado ostenta su desdén por los poderosos, también frecuenta a las familias de abolengo, como los Anchorena, o es beneficiado por el mecenazgo de Cecilia Benedit, quien solventa la publicación argentina de Ferdydurke. Atendiendo a la cronología que el mismo Gombrowicz anota en su diario, Amícola señala: "si la fama de bohemio la ganó en el comienzo de su permanencia entre los argentinos, esa rotulación quedó impresa en su personalidad y le costó deshacerse de ella. Su fama en Francia a su regreso a Europa sorprendió a moros y cristianos, salvo al mismo Gombrowicz, que había fijado como meta de su proyecto la trascendencia pública a pesar del ostracismo argentino" (143). 
hubiera asimilado al resto de los conferencistas polacos que clamaban por la liberación de su país y escribían textos comprometidos. ${ }^{30}$

Gombrowicz le provee a Saer la imagen de un viajero que escribe y funda desde la intemperie una literatura y una lengua que, como postulará Piglia, modifica el español rioplatense y las redes de la tradición de la novela argentina. Colocado en la serie de escritores contemporáneos, Gombrowicz será vinculado a Borges. En "La perspectiva exterior" Saer reexamina la conocida conferencia borgeana "El escritor argentino y la tradición”. En primer lugar y según la formulación de Saer, Borges y Gombrowicz reactualizan un debate siempre presente en la cultura argentina y ponen en primer plano el conflicto que se establece entre un nacionalismo excesivo, de tipo reactivo, y un deslumbramiento, también excesivo, por la literatura europea. En su ensayo, Saer reconstruye una serie de escenas -reales y ficcionales- en las que Gombrowicz y Borges aparecen como los duelistas de Transatlántico o como los escritores invitados a una cena catastrófica que reescribe en clave nacional la también frustrada cena entre Joyce y Proust. De esos desencuentros -en los que se mezclan la indiferencia borgeana y los mordaces comentarios de Gombrowicz hacia Borges-, Saer es el mediador, el juez que, avalado por su posición en la historia de las generaciones, puede juzgar ecuánimemente los testimonios y comportamientos de ambos duelistas. A partir de aquí Saer se encarga de desmontar las supuestas diferencias entre ambos para

\footnotetext{
${ }^{30}$ Esta resistencia de Gombrowicz no significa, sin embargo, que desconozca el escenario político europeo, pero su ficción procesa oblicua y contradictoriamente la experiencia bélica que estaba atravesando Polonia. Por un lado, como se recordará, la "Contienda sangrienta" del otro lado del océano amenaza la vida de los emigrados polacos y se proyecta, deformándose y "rebajándose", en distintas manifestaciones de violencia, como en la pantomima del Duelo de Transatlántico entre el Padre, Tomasz y Gonzalo: "y mientras allá silbaban las Balas, también aquí aparecía la Bala (a pesar de que todo debía desarrollarse con Pólvora y sin Balas)" (91) o durante las escenas de tortura en el sótano de los Caballeros de la Espuela. En el lugar de la proclama y la exaltación de los valores patrióticos, Gombrowicz instala el Vacío, como una experiencia que desarticula cualquier pretensión de sentido: "Y pensé que aquél debía ser el fin de nuestra vieja Patria... Sin embargo, fue un pensamiento Vacío, Vacío, y de nuevo me encontré en la calle, pero mientras caminaba no sabía siquiera adónde me estaba dirigiendo [...] Y en aquel momento sentí ganas de ver al Hijo [...] iQue reviente el Padre! El Hijo sin el Padre. El Hijo Liberado" (95-97).
} 
enfatizar, en cambio, sus equivalencias, ${ }^{31}$ aquellas que, por ser estrictamente contemporáneos, despiertan “idéntica pasión” en los lectores:

Hay otro punto inesperado en el que coinciden: la atracción por lo bajo. El culto al coraje, la predisposición a entrevistar proxenetas diestros en el uso del cuchillo y a ver en los diferendos entre matones de comité un renacimiento de la canción de gesta, equivalen en Borges a la inclinación de Gombrowicz por la adolescencia oscura y anónima de los barrios pobres de Buenos Aires. (“La perspectiva exterior" 27)

Y concluye que resuelven de la misma manera el problema de la tradición, dialogando "desde esas orillas remotas, con la cultura occidental" (Saer, "La perspectiva exterior" 28). Sin embargo, lo que Saer no puede leer es la diferencia "tonal" que caracteriza el duelo entre Borges y Gombrowicz, porque allí donde ambos coinciden, es cierto, en atacar la claridad y la pureza del arte, lo hacen de distintas maneras. Gasparini subraya a este respecto los "distintos platos" del exilio (el duelo de Transatlántico lee el "gusto" literario a través de las variantes aberrantes o sofisticadas del gusto culinario) y opone a los platos escandalosos de Gonzalo (personaje que funciona como el doble radicalizado y filiátrico de Gombrowicz) que apenas pueden "tragarse", los elaborados platos que Borges saborea imaginariamente para corregir, mediante la remisión a la cita, la irreverente pretensión de originalidad del brutal escritor polaco recién llegado. ${ }^{32}$ En el "Final"

${ }^{31}$ En “¿Existe la novela argentina?”, Ricardo Piglia también subrayará sus equivalencias en relación a cómo escribir desde una cultura secundaria y en una lengua marginal, y señalará una afinidad de estrategias en este uso irreverente de la tradición: "Para Borges (como para Gombrowicz) este lugar incierto permite un uso específico de la herencia cultural: los mecanismos de falsificación, la tentación del robo, la traducción como plagio, la mezcla, la combinación de registros, el entrevero de filiaciones" (51).

${ }^{32}$ Interrogada sobre el famoso banquete con Sur, Silvina Ocampo confiesa que antes de servir a los invitados, se le cayó una fuente de las manos. Gombrowicz fue el único que escuchó el ruido y se acercó: "Creía que estaba llorando. Me propuso que lo recogiese todo y lo sirviese como si nada. Y todo el mundo se sirvió. Había pedido a Witold que guardase el secreto, y en el curso de la comida me lanzaba ojeadas cuando mis amigos decían que la comida estaba muy buena" (Gombrowicz Rita s/p). Un plato elaborado, seguramente, pero ahora sucio y mezclado, que 
de sus Peregrinaciones argentinas, Gombrowicz confiesa que mientras paseaba por distintas partes del país y escribía su diario, también preparaba una novela que no les gustaría a los polacos: "no sirvo para guisar los platos que pueden encontrar en cualquier restaurante $[\ldots]$ lo que quiero es prepararles un guiso que haga que la lengua se les vuelva como un estropajo, que los ojos se les salten de las órbitas" (154). La equiparación que tanto Saer como Piglia trazan entre Borges y Gombrowicz pretende igualar procedimientos e inclinaciones por lo "bajo" que no pueden ser tan fácilmente asimilables sin aplanar la singularidad provocadora y contradictoria, procaz, de Gombrowicz, ni la sobriedad épica, pretendidamente nostálgica de Borges. ${ }^{33}$

La contemporaneidad, ${ }^{34}$ excéntrica, del escritor polaco se proyecta tanto sobre la serie de otros viajeros y conferencistas emigrados - Roger Caillois- como sobre los escritores de la escena nacional -Borges y Sur-; y a la vez abre una temporalidad que se vuelve contemporánea de la de Saer, porque como se verá, ambos comparten similares modos de pensar la patria y la escritura desde una noción amplia de extranjería.

Gombrowicz les hace "tragar" y "disfrutar" a los comensales de Sur, aliado momentáneo de la otra "salvaje" del grupo. Cfr. "Silvina Ocampo: la comida con Sur".

${ }^{33}$ En "Dislocación e intemperie: el viaje de vuelta" Sylvia Molloy desarticula la hipótesis de la nostálgica reconstrucción borgeana de las orillas, para señalar que la ciudad que "inventa" Borges cuando regresa de Europa no es la de su recuerdo (cuando él parte en 1914 Buenos Aires ya era una ciudad en vías de modernización) sino una ciudad premoderna, arcaica, cuyo potencial radica precisamente en que no le recuerda "nada".

${ }^{34}$ Para pensar esta afinidad entre Saer y Gombrowicz se recuperan las reflexiones de Giorgio Agamben, quien en "¿Qué es lo contemporáneo?" advierte que la contemporaneidad implica una relación singular con el tiempo porque adhiere a él: "a través de un desfase y un anacronismo" (17-8). Precisamente, por no coincidir del todo con su hora, por mantenerse a distancia, el sujeto contemporáneo es "aquel que mantiene la mirada fija en su tiempo, para percibir, no sus luces, sino su oscuridad. [...] es aquel que sabe ver esa oscuridad, aquel que está en condiciones de escribir humedeciendo la pluma en la tiniebla del presente" (21). Como se verá, tanto Saer como Gombrowicz comparten esa posición de observación privilegiada, una "perspectiva exterior" que no sólo adquiere valores espaciales y geográficos, sino también temporales, y que les permite alejarse y suspender las morales de una época para percibir, no sus luces, sino sus sombras. Sin embargo, como continúa explicando Agamben, ese alejamiento no implica indiferencia: "contemporáneo es aquel que percibe la oscuridad de su tiempo como algo que le incumbe y no cesa de interpelarlo, algo que, más que cualquier luz, se dirige directa y singularmente a él. Contemporáneo es aquel que recibe en pleno rostro el haz de tiniebla que proviene de su tiempo" (22). En este sentido, las poéticas de ambos escritores "se dan cita" fuera de hora, en su forma de comprender el exilio y de indagar las potencias de una escritura no complaciente con los valores de la cultura y la sociedad de su tiempo. 


\section{Exilios impropios: azar y ceguera en Saer y Gombrowicz}

Saer y Gombrowicz se vuelven contemporáneos en la impropiedad del exilio: ${ }^{35}$ allí donde ambos resisten las expectativas políticas de compromiso con causas nacionales (y latinoamericanas); privilegian el aislamiento o el anonimato frente a la gregariedad institucional y no se unen al grupo de sus compatriotas también exiliados ni se asimilan a la escena literaria que los acoge. Ambos interrogan la fidelidad entre literatura y nación y proveen versiones anómalas e inestables, contradictorias, de la patria. En Saer, la nacionalidad es efecto de la contingencia y el azar: "no hay ningún lugar ni acontecimiento predestinados: nuestro nacimiento es pura casualidad. Que de esa casualidad se deduzca un aluvión de deberes me parece perfectamente absurdo" ("Razones" 10). ${ }^{36}$ Frente a la "patria"

${ }^{35}$ En "La existencia exiliada" Jean-Luc Nancy procura releer el tópico de la existencia como un exilio, de raíces greco-judeo-cristianas, en el marco de la enorme cantidad de éxodos, desplazamientos, deportaciones y migraciones a nivel mundial, donde el exilio ha dejado de simbolizar un "pasaje con retorno" para transformarse en una experiencia definitiva sin regreso: "Parece, pues, como si hubiera una especie de exilio constitutivo de la existencia moderna, y que el concepto constitutivo de esta existencia fuera él mismo el concepto de un exilio fundamental: un 'estar fuera de', un 'haber salido de' " (Nancy 36). De esta manera, busca desarticular la idea del exilio como la salida de lo propio y como algo transitorio, dialectizable en los términos de ida y retorno. Por el contrario, apuesta por un exilio no dialectizable que sea él mismo lo propio: "Se trata entonces de pensar el exilio, no como algo que sobreviene a lo propio, ni en relación con lo propio -como un alejamiento con vistas a un regreso o sobre el fondo de un regreso imposible-, sino como la dimensión misma de lo propio" (Nancy 38). Frente a las formas alienadas y cristalizadas de "lo propio" (contra las cuales escriben Saer y Gombrowicz): propiedad, nación y familia, Nancy apuesta por la idea de "asilo": "Pensar el exilio como asilo [...] es justamente pensar el exilio como constituyendo por sí mismo la propiedad de lo propio" (Nancy 38).

${ }^{36}$ En "Política del exilio" Giorgio Agamben desmonta precisamente la ficción implícita de la relación entre el simple nacimiento, la vida desnuda, y la adscripción a una nación, fundamento de la vocación "nacional" y biopolítica del estado moderno (siglo XIX y XX). Los refugiados, señala, ponen en crisis esta ficción originaria y permiten cuestionar esa continuidad entre hombre y ciudadano. Agamben sigue los avatares históricos de esta relación y advierte que después de la Primera Guerra Mundial ese vínculo nacimiento-nación ya no podía seguir ejerciendo sus funciones legitimadoras. Por eso, propone pensar a "refugiados" y "exiliados" por lo que verdaderamente son: "un concepto límite que pone en crisis radical las categorías fundamentales de la Nación-Estado, desde el nexo nacimiento-nación hasta el de hombre-ciudadano" (Agamben, "Política del exilio" 46-7). La propuesta de Agamben es resituar la figura del exilio para dejar de pensarla como una figura política marginal y comenzar a pensarla -como se hacía en la filosofía clásica- como un concepto filosófico-político fundamental que permite desarmar "la espesa trama de la tradición política todavía hoy vigente" (52). Como puede observarse, Saer cuestiona precisamente ese vínculo entre el nacimiento y los deberes "patrióticos" de un sujeto y comparte esa deriva del exilio desde sus contingencias políticas hasta su condición ontológica como la única 
como abstracción y suma de imágenes sociales predeterminadas, Saer la piensa como adherencia material y temporal:

Para mí la patria es ese lugar en su sentido más estricto y material. Lo nacional es la infancia, y es por lo tanto regional, e incluso local. La materialidad de la patria se confunde con mis experiencias y está constituida por la existencia precisa de paisajes, caras, nombres, experiencias comunes. [...] Por eso a veces me sé decir que todo regreso es imposible, ya que esa patria que nos parece persistir en el espacio no es otra cosa que una experiencia intensa vivida en un pasado irrecuperable. El regreso podría ser, en ese caso, una nueva forma del exilio. (Ensayos 150)

La adscripción de lo nacional a la infancia y al ámbito estricto de las experiencias materiales que el sujeto vivió en el pasado permite vincular el pensamiento saeriano con el de otros exiliados que también piensan en términos de temporalidad humana. Gasparini subraya esa insistencia en personalidades tan disímiles como las de Jean Améry y Gombrowicz, quien, como se sabe problematiza la nación en Transatlántico tensionando los términos de vejez y juventud: retorno a la Patria, al Padre y al pasado o apertura indeterminada de la Filiatría. Saer no sólo desarticula la nostalgia asociada al regreso a la tierra natal, "nueva forma del exilio", sino que también muestra que esa indeterminación que Gombrowicz asociaba a la juventud aún "informe” también podía encontrarse en la vejez iconoclasta y procaz de algunos viejos renegados: los personajes de Washington Noriega e Higinio Gómez, pero sobre todo el escritor chino Koei, protagonista de uno de los relatos más anómalos de Saer, "Las instrucciones familiares del letrado Koei”. Este texto menor radicaliza sin embargo su posición para mostrar que ni la vejez es una experiencia sólida, nítida y cercana a la

esfera posible en la que los artistas pueden sustraerse de los condicionamientos sociales y volver artísticamente productiva su separación. 
sabiduría, ni la patria es siquiera asimilable a las ideas de territorio, idioma e infancia. ${ }^{37}$

Esa impropiedad del exilio que tanto Gombrowicz como Saer prueban contra las formas alienadas de lo propio: nación, herencia y tradición, se despliega en sus indagaciones sobre la literatura como experiencia radical de extranjería. En su Diario argentino Gombrowicz abjurará de las abstracciones y de los grandes "valores" de la cultura para sostener que el arte debe destruir la realidad, descomponerla en elementos y construir con ellos nuevos mundos absurdos. Frente a quienes le exigen al arte una claridad "clásica", postulará en cambio un arte de la nocturnidad y la ceguera:

Su claridad [la del arte] es nocturna, no la del día. Su claridad es precisamente igual a la de una linterna que extrae de las tinieblas un objeto, sumergiendo el resto en la oscuridad más insondable. Debe ser -fuera de los límites de la luz-oscura como la sentencia de una pitonisa de rostro velado, no dicha sino hasta el final, tornasolada por multitud de significados y más amplia que la razón. [...] Hay que ir en pleno mediodía

${ }^{37}$ El relato, incluido precisamente en la sección llamada "Márgenes" de Juan José Saer por Juan José Saer, recoge el único fragmento que quedó de las "instrucciones familiares" que era costumbre que los ancianos dejaran a sus descendientes antes de morir. Sin embargo, aquí la escritura defrauda las expectativas moralizantes del género y ofrece en cambio una descarada confesión de los "pecados" del letrado, una especie de autobiografía infame que examina su decisión de abandonar sus funciones en la corte imperial de China cuando esta fue invadida y dominada por los mongoles. El relato desarticula la concepción de que exista, efectivamente, una patria a la cual el individuo está unido por una serie de deberes cuyo cumplimiento lo volverían ese anciano venerado por los jóvenes. Por el contrario, Koei no se alejó de la corte imperial por amor a la patria, en primer lugar porque desconocía gran parte de su extensa geografía; tampoco había tomado esa decisión en favor de su "patria" personal -su familia, su trabajo, algunos amigos- puesto que verdaderamente no peligraban con el cambio de administración; la patria tampoco podía definirse por el territorio o el idioma, precisamente porque la lógica del imperio estaba hecha de continuos desmembramientos y anexiones, y en él convivían múltiples lenguas y dialectos. La patria, finalmente, tampoco podía circunscribirse a la casa, la infancia y los recuerdos, porque la naturaleza misma de la infancia es refractaria a los cambios de gobierno y el lugar de nacimiento es contingente. Koei, es, antes que autor de comedias dramáticas o escritor errante, un filósofo nihilista que niega que los actos obedezcan a algún tipo de justificación y se opone a esas grandes "abstracciones" de las que renegara también Gombrowicz, porque lo único que puede dejarle a sus descendientes al final de su vida es "incertidumbres y porvenir" (55). 
a contemplar la Venus más clásica para encontrar en ella la noche más oscura. (Diario 93)

En "Narrathon" (1973) Saer utilizará una imagen similar: "Pero la modestia reside en hablar, en tanto que ciego, a los demás, para que vean, no la realidad, o una realidad, sino más bien la ceguera de que sufren y de la que, en la mayoría de los casos, no son conscientes más que a medias" (Saer, El concepto de ficción 142). Los escritores, filósofos y poetas forman: "Un círculo de miradas semienceguecidas, alrededor de una catástrofe común" (142).

Poéticas del sopor, la somnolencia, la miopía y el sueño: Gombrowicz y Saer describen de manera similar la tarea del artista que abjura de las totalizaciones de la razón y la cultura. Ambos apuestan por las incertidumbres de una percepción paradojal, sostenida sobre la fragilidad de los sueños (la lógica onírica permea varias entradas del Diario), ${ }^{38}$ los recuerdos y los manchones de mundo que alcanza a vislumbrar el semiciego. ${ }^{39}$ El final de "Carta a la vidente": "De un hombre que cabecea, entonces, qué se puede esperar? Nada como no sea una hilera de fragmentos, espesos, en bruto. Que el mundo resplandezca en ellos, si uno de los modos del mundo es el resplandor" (211); parece evocar el siguiente fragmento del Diario: "el sueño destruye la realidad cotidiana del día, extrae de ella ciertos trozos, extraños fragmentos, y los dispone absurdamente en un dibujo arbitrario... pero para nosotros ese sinsentido es precisamente el sentido más profundo" (92).

\footnotetext{
${ }^{38}$ Esa perfección artística del sueño que Gombrowicz exalta puede seguirse en varias entradas del Diario. Podría mencionarse el hallazgo de un "ojo humano" en la cubierta del barco que lo lleva de regreso a Europa, después de que su propia mirada hubiera quedado prendida de algunas esquirlas azarosas en el puerto de Buenos Aires, y luego atenta a la desaparición progresiva del paisaje familiar; y también el encuentro con su yo de la juventud a bordo de un Chobry fantasmal en mitad del océano. Momentos en que el sujeto oscila y se abisma en visiones, vislumbres y contradicciones imposibles de entender bajo la lógica diurna de la razón.

${ }^{39}$ La mayor (1976) podría leerse en este sentido como una extensa declinación tonal que va del ojo a la mano. El narrador saeriano se sustrae de la tradición de los iluminados (Artaud y Rimbaud) y, anulándola, la transgrede. "Carta a la vidente" reemplaza en este sentido la visión, el ojo del vidente, por la musa más modesta de la mano que se mueve en la penumbra y tantea a ciegas trozos de mundo -"Mi musa, es, si se quiere, manual" (211) - para extraer, de pronto, resplandores mínimos: la mancha amarilla de la bufanda que se enciende hacia el final de "La mayor" cuya clave poética puede leerse en "Recuerdos".
} 
La crítica artística y literaria de Gombrowicz, fundada desde la intemperie, le permitirá exigirle a la literatura argentina que abandone su "condición escolar" y relativizar, como lo hará Saer, la infalibilidad europea. ${ }^{40}$ En el Diario argentino parodia las distintas alternativas que los intelectuales de Latinoamérica ensayan ante la ausencia de una "gran literatura": "romper con Europa, volver a encontrar al indio de hace cuatrocientos años", retornar "a la Patria España y a la Madre Iglesia Católica", "estudiar a Marx” o apelar al más fino cosmopolitismo (las opciones son, consecuentemente, las que dan los nacionalistas, conservadores, izquierdistas e internacionalistas de Sur) y diagnostica: "El problema principal para estos artistas no es expresar su pasión y construir un mundo, sino escribir una novela de 'nivel europeo' para que Argentina, para que América del Sur, logre al fin su papel representativo" (Gombrowicz 123). Esta oposición crítica al papel legitimador de Europa se expresará también cuando asuma su regreso. Enfermo y débil Gombrowicz ingresa a París, ciudad que no visitaba desde 1928, en que la dejó siendo un estudiante insignificante y desconocido, y se autoimpone una consigna: "como literato debía aislarme de París" (265), debía ser su enemigo porque París representaba esa madurez de la que quería escapar:

Conocía desde tiempo atrás las fuentes ocultas de mi fobia parisina, sabía que esta ciudad tocaba mi parte más sensible, la edad, el problema de la edad, y es cierto que si estaba en riña con París era debido a que se trataba de una ciudad 'que pasaba de los cuarenta'. (Diario 264)

Como ya se ha señalado, Gombrowicz terminará consagrándose en Europa como escritor. Interesa sin embargo retener esa actitud refractaria a la ciudad luz,

\footnotetext{
${ }^{40}$ En "Sobre la cultura europea" (1988), también incluido en El concepto de ficción, Saer desarticula "el deslumbramiento, secreto o confesado, por la literatura europea" y denuncia la falacia de los valores humanistas sobre la que se sigue legitimando su utopía. Se pregunta si el concepto mismo de tradición universal, "como concepción de la historia, no es una superstición" (86) y reconociendo irónicamente la "riqueza artística, científica y filosófica del continente" (86) afirma que los tan mentados "escritores europeos" no son sino escritores exiliados de esa tradición, que escriben en su contra.
} 
que en Saer era al comienzo "indiferencia", destino involuntario, y más tarde, voluntaria separación "provinciana" ${ }^{41}$ Esa contemporaneidad entre las poéticas de Saer y Gombrowicz, leída en el marco de sus respectivos viajes, adquiere entonces un inusitado espesor político y estético.

\section{Conclusiones}

"De hoja seca y anónima llevada por el viento de la contingencia, [...] pasó a ser, de toda intemperie, signo, paradigma y emblema". (Saer, "La perspectiva exterior" 315)

La larga estadía de Gombrowicz en Argentina demuestra que la “contingencia" del atípico exilio gombrowicziano puede devenir "paradigma" de la intemperie. La reflexión saeriana sobre Gombrowicz insiste en la importancia radical que la experiencia argentina tuvo en su vida y sobre todo en su literatura (algo que él mismo afirma en el prefacio de su Diario). Efectivamente, apunta Saer, Gombrowicz envejece en Argentina y es allí donde advierte con pánico el florecimiento de "una red sutil de arrugas que aparecían sobre la frente" (Diario 51 ), pero sobre todo, es en este país donde se produce su madurez literaria. ${ }^{42}$

En El río sin orillas, la última imagen que cierra el retrato del escritor es la de un Gombrowicz fantasmal que, junto a "ese ejército de fantasmas que generan las noches argentinas" (158) -Roberto Arlt, Martínez Estrada, Macedonio Fernández; y en la orilla oriental, Felisberto Hernández y Onetti- dejaron textos

${ }^{41}$ Si durante su vida y su carrera literaria en Santa Fe y Rosario Saer desarticula las tajantes oposiciones entre capital e interior, afirma en cambio su "provincialismo" en París: "Nunca fui muy afrancesado y nunca quise conocer los lugares de los escritores. [...] Respecto a las tramas literarias, en París también existe un enjambre infernal pero yo no tengo nada que ver con eso. Cuando leo a los escritores franceses es como si todavía estuviera leyéndolos en Santa Fe. [...] Se supone que los que viven en París tienen que estar todo el tiempo haciendo una vida literaria pero París es una ciudad como Buenos Aires. Uno puede vivir en un barrio alejado y no conocer a nadie" (Speranza 102).

42 "En Ferdydurke, escrita antes del viaje, el punto de vista es el de la juventud; en La pornografia, el de los adultos. En Transatlántico - una de sus obras maestras- el narrador es, según los medios sociales que frecuente, alternativamente objeto o sujeto de seducción. Esa madurez perfecciona su método narrativo multiplicando la variedad de puntos de vista hasta darle a sus primeras intuiciones, como sucede en la evolución de toda gran literatura, la complejidad de un sistema" (Saer, "Perspectiva exterior" 22). 
admirables. Gombrowicz ingresa aquí en una nueva y última serie: el entramado de escritores rioplatenses, exiguo y riguroso, que Saer configura como su biblioteca personal. Gombrowicz es, en su escritura ensayística, en la textura heterogénea de sus Libretas, y en la apuesta por una literatura semiciega, la cifra resistente que le permite ir y volver a la Argentina; es su aliado en la forma más radical del exilio, rebelde como él a los "compromisos del escritor", resistente a las abstracciones y valores de la Identidad, la Cultura y la Patria, reacio, por fin, a la exhibición innecesaria de un "yo" que más bien se ausenta, contradictorio y nunca estable, en las formas sustractivas del Diario.

Como intentó mostrarse, Saer indaga la figura de Witold Gombrowicz en un momento significativo de su trayectoria y lo incorpora en dos series de intelectuales y viajeros a partir de las cuales traza las singularidades del escritor polaco y proyecta sus propias preocupaciones y elecciones estéticas y políticas. Sin embargo, cada vez que se mira en Gombrowicz, como si respondiera a esa consigna generacional propuesta por Germán García, corre el riesgo de deformarse. El escritor polaco es, como él, un extranjero que puede capturar manchones de mundo, distorsionando la mirada que se presenta en el momento de su alejamiento; pero también es la potencia exótica de la selva que se derrama y excede la pretendida neutralidad de la zona saeriana. Gombrowicz, al igual que Saer, sortea la preponderancia del centro urbano porteño, pero sobrepasa los umbrales territoriales de lo nacional para abrir la inmensidad -olvidada, negada- del "informe e inmaduro" país a los vientos intercontinentales, y allí cuando registra monotonía (en la belleza demasiado corriente de Santiago del Estero, en la final ordenación paisajística de la naturaleza sublime y sobrecogedora del Aconcagua), exige, en cambio, distinción y brillantez. ${ }^{43}$

\footnotetext{
${ }^{43}$ La visión perturbadora del Aconcagua ("los torbellinos y la tensión de la materia" que exceden la "confirmación intelectual" y el enunciado capaz de comunicar "la inmensidad") termina decepcionando a Gombrowicz cuando sobreviene el orden estético del paisaje: "resulta doloroso constatar que semejante tensión de elementos dispares, a esa escala, se resuelve en armonía y equilibrio [...] Aquí me encuentro con la misma decepción: la grandeza se ha perdido en armonía, como si domada por las proporciones, dejara de existir" (Peregrinaciones 69). Lo mismo le había ocurrido con el sentimiento de la belleza de las mujeres y los hombres de Santiago del Estero, una
} 
El escritor polaco es, como Saer, un viajero insólito, un exiliado rebelde a los compromisos, un solitario cuyo aislamiento es la moneda resistente a la gregariedad aplanadora, y desde la doble orilla remota, intercambiable, de Polonia y Argentina, -como Borges y Saer- problematiza la fidelidad que las literaturas le deben a la nación y la superioridad que le atribuyen a la cultura europea. Sin embargo, el gusto por lo bajo, la verborragia vanguardista de su lengua, la mezclas aberrantes y sabrosas de sus "platos", no son equivalentes a los mecanismos que Borges esgrime para dirimir las relaciones entre literatura nacional y cultura universal. Una vez más, Gombrowicz traza, no sólo sobre sus contemporáneos, sino también sobre Saer, una diferencia difícil de "tragar". Esa "tradición potencial" en la que podría inscribirse a Gombrowicz, cuya radicalidad se vuelve más perentoria cuanto más intenta asimilárselo, se asienta y reescribe restos incalculados del pasado y mantiene latente la posibilidad de nuevos desprendimientos filiátricos.

\section{Bibliografía}

Agamben, Giorgio. "Política del exilio". Archipiélago. Cuadernos de crítica de la cultura. Barcelona, no. 26-27, 1996, pp. 41-52.

. "Elogio de la profanación". Profanaciones. Adriana Hidalgo, 2009, pp.99-119.

. ¿Qué es lo contemporáneo?”. Desnudez. Adriana Hidalgo, 2011, pp. 17-29.

Aira, César. "Exotismo". Boletín/3 del Centro de Estudios de Teoría y Crítica Literaria, 1993, pp. 73-79.

belleza que, carente de lo maravilloso, inconsciente de sí, se resolvía finalmente en monotonía cotidiana. 
Amícola, José. "El diario trans-atlántico de Witold Gombrowicz”. Zama /4 DOSSIER, 2012, pp.137-146.

Blanchot, Maurice. El espacio literario. Paidós, 2015.

Contreras, Sandra. Las vueltas de Cesar Aira. Beatriz Viterbo, 2002.

Dalmaroni, Miguel. "Lo incalculable. Saer en la escuela argentina". Otra Parte. Revista de artes y letras, no. 18, 2009, pp. 46-50.

. “El largo camino del 'silencio' al 'consenso'. La recepción de Saer en la Argentina (1964-1987)”. Saer, Juan José. El entenado - Glosa. Edición crítica, coordinada por Julio Premat. CRLA; Alción Editora (Colección Archivos), 2010, pp. 607-663.

Freixa Terrada, Paula. “Gombrowicz como personaje de ficción en la literatura argentina”. El fantasma de Gombrowicz recorre la Argentina, editado por Nicolás Hochman. Heterónimos, 2016, p. 153-164.

Gerbaudo, "Irrecibible, monstruoso, inclasificable". Zona de prólogos, compilado por Paulo Ricci. Seix Barral, 2011, pp. 173-185.

García, Fernando. "Saer en la ruta del adiós a su geografía literaria”. AA.VV. Una forma más real que la del mundo. Conversaciones con Juan José Saer, compilado por Martín Prieto. Mansalva, 2016, pp. 189-195.

García, Germán. “Leer a Gombrowicz". Los libros, no. 2, agosto de 1969, p. 12. Gasparini, Pablo. El exilio procaz: Gombrowicz por la Argentina. Beatriz Viterbo Editora, 2006.

Gombrowicz, Witold. Diario argentino. Adriana Hidalgo, 2006. . Peregrinaciones argentinas. El Cuenco de Plata, 2016. . Trans-Atlántico. El Cuenco de Plata, 2015.

Gombrowicz, Rita. "Silvina Ocampo: la comida con Sur” (conversación entre Rita Gombrowicz y Silvina Ocampo). Suplemento Radar, Página/12, domingo 8 de junio de 2008. www.pagina12.com.ar/diario/suplementos/radar/subnotas/4650-7622008-06-08.html 
Hochman, Nicolás. "Exilio y paralaje”. Letras Históricas, no. 4, enero-junio de 2011, pp. 121-138.

Manzi, Joaquín. “1939 y después: el largo invierno austral de Gombrowicz”. Historia crítica de la literatura argentina, dirigido por Noé Jitrik, Tomo 7, Rupturas, dirigido por Celina Manzoni. Emecé, 2009, pp. 411-436.

Molloy, Sylvia. "Dislocación e intemperie: el viaje de vuelta". Caracol. Revista do programa de pós-graduação da Área de Língua Espanhola e Literaturas Espanhola e Hispano-Americana do Departamento de Letras Modernas, no. 10, 2015. www.revistas.usp.br/caracol/article/view/114538

Nancy, Jean-Luc. "La existencia exiliada". Archipiélago. Cuadernos de crítica de la cultura, no. 26-27, 1996, pp. 34-40. www.redalyc.org/pdf/815/81500813.pdf

Oubiña, David. El silencio y sus bordes. Modos de lo extremo en la literatura y el cine. FCE, 2011.

Patruno, Luigi. Relatos de regreso. Ensayos sobre la obra de Juan José Saer. Beatriz Viterbo Editora, 2015.

Piglia, Ricardo. “¿Existe la novela argentina?”. Crítica y ficción. Siglo XX, 1990, pp. 49-57.

Premat, Julio. "Saer: un escritor del lugar". Héroes sin atributos. Fondo de Cultura Económica, 2009, pp. 167-202.

Saer, Juan José. "Carta a la vidente”. La mayor. Cuentos completos. Seix Barral, 2004, pp. 210-211. . El río sin orillas: tratado imaginario. Seix Barral, 2003.

. "La perspectiva exterior: Gombrowicz en Argentina", "Sobre la cultura europea” y "Narrathon”. El concepto de ficción. Seix Barral, 2004, pp.17-29, 85-88 y 139-151.

. Libretas de viaje. Papeles de trabajo II. Borradores inéditos. Seix Barral, 2013, pp. 273-335. 
CATEDRAL Tomada: Revista de crítica literaria latinoamericana / Journal of Latin American Literary Criticism Exilios impropios y peregrinación profana: Juan José Saer y Witold Gombrowicz

. "Razones" y "Las instrucciones familiares del letrado Koei". Juan José Saer por Juan José Saer editado por Jorge Lafforgue. Celtia, 1986, pp. 924 y $45-55$.

. "Rubén en Santiago". El arte de narrar. Seix Barral, 2000, pp. 69-72.

. "Una de las propuestas principales de Nadie nada nunca..." y "El pintor Fernando Espino". Ensayos. Borradores inéditos. Seix Barral, 2015, 143-154 y 192-196.

Sarmiento, Domingo F. Facundo o civilización y barbarie en las pampas argentinas. Centro Editor de Cultura, 2005.

Scott, Edgardo. Caminantes. Ediciones Godot, 2017.

Speranza, Graciela. "Entrevista con J. J. Saer”. AA.VV. Una forma más real que la del mundo. Conversaciones con Juan José Saer, compilado por Martín Prieto. Mansalva, 2016, pp. 95-103. 